\title{
Exercise-induced airway obstruction in relation to chronic obstructive lung disease
}

\author{
F. G I MEN O ${ }^{1}, W . C h r$. BER G ${ }^{1}, E$. J . STE ENHUIS ${ }^{1}$, \\ K. de VRIES ${ }^{2}$, R. PESET, and H. J. SLUITER ${ }^{2}$ \\ Lung Function Laboratory and Department of Asthmatic Diseases, Sanatorium Beatrixoord, \\ Haren (Groningen), ${ }^{1}$ and \\ Pulmonary Function Laboratory and Department of Lung Diseases, Medical Department, \\ University Hospital, Groningen, The Netherlands ${ }^{2}$
}

\begin{abstract}
Gimeno, F., Berg, W. Chr., Steenhuis, E. J., de Vries, K., Peset, R., and Sluiter, H. J. (1974). Thorax, 29, 16-20. Exercise-induced airway obstruction in relation to chronic obstructive lung disease. Forty-two patients with chronic obstructive lung disease and clinically suspected exercise-induced airway obstruction were studied to ascertain whether those with proven exercise-induced airway obstruction had specific distinguishing features. Exercise-induced airway obstruction (defined as a fall of $\mathrm{FEV}_{1}$ of at least $10 \%$ of the pre-exercise values) was detected in 20 of the 42 patients. These 20 were found to have a lower elastic recoil but were otherwise identical with the remainder as regards clinical and physiological abnormality. It is postulated that exercise-induced airway obstruction can be a manifestation of chronic obstructive lung disease.
\end{abstract}

Previous studies by a number of investigators have documented the effects of exercise on various aspects of pulmonary function in exercise-induced airway obstruction. Some investigators reported this phenomenon in a large percentage of young patients with uncomplicated asthma as defined by the CIBA Foundation Symposium (1959). Other studies (Fisher, Holton, Buxton, and Nadel, 1970; Vasallo, Gee, and Domm, 1972) were undertaken to define more fully the nature of the abnormal response to exercise.

In adult patients exercise may be the only factor which precipitates airway obstruction (Crompton, 1968; Stanescu and Teculescu, 1970). Unfortunately, it has been difficult from most reports to deduce the extent of chronic obstructive lung disease, as defined by Orie, Sluiter, de Vries, and Tammeling (1961) and Fletcher (1961) in these patients with exercise-induced airway obstruction. The present study was undertaken to delineate further this category of patients in relation to chronic obstructive lung disease and to some of the symptoms of this disease.

\section{SUBJECTS AND METHODS}

Patients in hospital with chronic obstructive lung disease who had experienced breathlessness after exer-

Requests for reprints to: Dr. F. Gimeno, Beatrixoord, Haren (Groningen), The Netherlands tion were referred to the laboratory for routine pulmonary function tests. The special procedures outlined below were explained to each subject in detail before participation in this study. All tests were made while the subjects were in a steady-state phase of their chronic lung disease. The tests were completed within a few days and no subject was clinically ill on the days of the study. The severity of the chronic obstructive lung disease was graded from 0 to 4 according to the prevalence of the following respiratory symptoms: cough, phlegm production, attacks of dyspnoea at rest, and breathlessness during exertion. The gradation was based on the history and clinical observation (Tammeling, Sluiter, Hilvering, and Berg, 1971). The age of onset of the disease was also included. The subjects were examined and inquiry was made concerning symptoms and signs of nasal disease. The results of allergy skin testing, histamine threshold concentration indicating bronchial hyperreactivity (de Vries et al., 1964), blood and sputum eosinophil counts, and smoking habits were recorded.

Measurement of vital capacity (VC), one second forced expiratory volume $\left(\mathrm{FEV}_{1}\right)$, and maximum voluntary ventilation (MVV) was performed with a Lode D 53R spirometer. Residual volume (RV) was determined by the closed-circuit helium dilution method. Total lung capacity (TLC) was calculated as the sum of VC and RV. Using the method of Hilvering (1963), transpulmonary pressure was measured as the pressure difference between the mouth and oesophagus with the subject in the sitting 
position. Transpulmonary pressure at full inspiration (PTL) was measured after a very slow maximal inspiration. Using a slow vital capacity manoeuvre, the quasistatic compliance was calculated from the rectilinear part of the expiratory volume-pressure curve above the level of the functional residual capacity.

The mean pressure (Pvisc), as the expression of mechanical work during spontaneous breathing, was derived from the volume pressure loop at rest (Pvisc $=$ surface area of the volume pressure loop divided by the corresponding tidal volume). Bronchodilatation was induced by intramuscular administration of $25 \mathrm{mg}$ of thiazinamium ${ }^{1}$. This is a drug with antihistaminic and anticholinergic properties (Booy-Noord et al., 1957), and the effect was measured 30 minutes after injection. Blood gas tensions were measured with Radiometer glass and membrane electrodes.

For the exercise test a Lode electric bicycle ergometer was used. The external work load given to the subjects was determined by their pre-exercise $F E V_{1}$ and by their sex and age. The exercise test was preceded by a warming-up period of one minute and its duration was six minutes in all studies. The six-minute exercise period was considered necessary for adjustment of respiration and circulation to the work load ( $\AA$ strand and Rodahl, 1970). The heart rate was monitored electrocardiographically and was recorded at the end of six minutes' exercise. The $F^{\prime} V_{1}$ was measured before exercise. Statistical analysis for significant differences between groups was performed using Student's $t$ test for lung function and laboratory data and the chi-square test for clinical data. We tested the hypothesis that there was no significant difference between group 1 and group 2 .

\section{RESULTS}

Twenty of the 42 patients studied had a postexercise decrease in excess of $10 \%$ of the preexercise $\mathrm{FEV}_{1}$ value and were allocated to group 1, while the remaining 22 patients were placed in group 2.

HISTORY AND CLINICAL FINDINGS (Table I) The two groups did not differ significantly with respect to age of onset of the complaints, incidence of cough and phlegm production, severity of dyspnoea and breathlessness during exertion, family history, smoking habits or presence of nasal disease. The mean age was the same in both groups (30 years) with a range of 14 to 59 years in group 1 , and 14 to 54 years in group 2 . There were 15 men and 5 women in group 1 and 18 men and 4 women in group 2. There was also no difference in the mean height and weight. The results of allergy testing, including skin tests and, in the case of positive

1Multergan (R.), Specia, Pas is, France results, of inhalation tests with house dust, fungi or pollen, were not significantly different in either group, as was the case with the histamine threshold concentrations and blood and sputum eosinophil counts. The individual data may be obtained from the authors on request.

T A B LE I

HISTORY AND CLINICAL FINDINGS

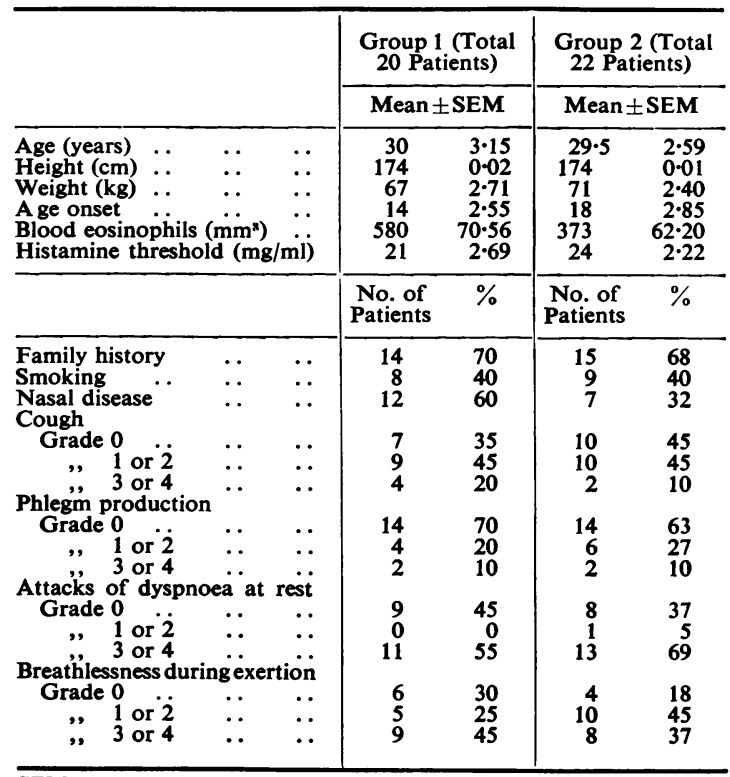

SEM = standard error of mean.

RESPIRATORY FUNCTION AND BLOOD GASES (Table II) The means of total lung capacity (TLC) and vital capacity (VC) as a percentage of the predicted values (Group 1: $\mathrm{TLC}=109 \%$ and $\mathrm{VC}=102 \%$; Group 2: $\mathrm{TLC}=100 \%$ and $\mathrm{VC}=98 \%$ ) were normal and similar in both groups. After bronchodilatation the means were about the same as before. The FEV 1 and MVV before bronchodilatation tended to be lower in group 1 although there were no significant differences between the means of the two groups. In both, the means of $F E V_{1}$ and MVV became normal after bronchodilatation. The mean of the pressure (Pvisc) to overcome the mechanical work during quiet breathing tended to be higher in group $1(\mathrm{P}<0.05)$; however, after bronchodilatation, all mean values were within the normal range. The quasistatic compliance was normal in both groups, but after bronchodilatation was slightly increased in group $1(\mathrm{P}<0.05)$; the values indicated abnormally compliant lungs. In group 1, the transpulmonary pressure at full inspiration $\left(\mathbf{P}_{\mathrm{TLC}}\right)$ was less than in group $2(\mathrm{P}<$ 
T A B L E I I

RESPIRATORY FUNCTION, BLOOD GASES, AND $\mathrm{pH}$ BEFORE AND AFTER THIAZINAMIUM

\begin{tabular}{|c|c|c|c|c|c|}
\hline & \multicolumn{2}{|c|}{ Group I } & \multicolumn{2}{|c|}{ Group II } & \multirow{2}{*}{$\begin{array}{l}\text { Sig- } \\
\text { nificance } \\
\text { of Dif- } \\
\text { ference of } \\
\text { Means }\end{array}$} \\
\hline & Mean & \pm SEM & Mean & \pm SEM & \\
\hline $\begin{array}{l}\text { TLC (I. BTPS): } \\
\text { Predicted } \\
\text { Before } 25 \mathrm{mg} \\
\text { i.m. of thia- } \\
\text { zinamium } \\
\text { After }\end{array}$ & $\begin{array}{l}6 \cdot 9 \\
7 \cdot 0\end{array}$ & $\begin{array}{l}0 \cdot 44 \\
0 \cdot 43\end{array}$ & $\begin{array}{l}6 \cdot 4 \\
6 \cdot 5\end{array}$ & $\begin{array}{l}0 \cdot 21 \\
0 \cdot 22\end{array}$ & $\begin{array}{l}\text { ns } \\
\text { ns }\end{array}$ \\
\hline $\begin{array}{l}\text { VC (l. BTPS): } \\
\text { Predicted } \\
\text { Before } \\
\text { After }\end{array}$ & $\begin{array}{l}4 \cdot 8 \\
4 \cdot 9 \\
5 \cdot 1\end{array}$ & $\begin{array}{l}0.22 \\
0.31 \\
0.32\end{array}$ & $\begin{array}{l}4.9 \\
4 \cdot 8 \\
5 \cdot 0\end{array}$ & $\begin{array}{l}022 \\
0 \cdot 15 \\
0 \cdot 18 \\
0 \cdot 16\end{array}$ & $\begin{array}{l}\text { ns } \\
\text { ns } \\
\text { ns }\end{array}$ \\
\hline $\begin{array}{l}\text { FEV }_{1}^{\text {(1. BTPS): }} \\
\text { Predicted } \\
\text { Before } \\
\text { After } \\
\text { MVV (I. BTPS/ } \\
\text { min): }\end{array}$ & $\begin{array}{l}3 \cdot 6 \\
3 \cdot 0 \\
3 \cdot 8\end{array}$ & $\begin{array}{l}0 \cdot 19 \\
0 \cdot 22 \\
0 \cdot 23\end{array}$ & $\begin{array}{l}3 \cdot 7 \\
3 \cdot 5 \\
4 \cdot 0\end{array}$ & $\begin{array}{l}0.13 \\
0 \cdot 18 \\
0.18\end{array}$ & $\begin{array}{l}\text { ns } \\
\text { ns } \\
\text { ns }\end{array}$ \\
\hline $\begin{array}{l}\text { min): } \\
\text { Predicted } \\
\text { Before } \\
\text { After } \\
\text { P visc. }\left(\mathrm{cmH}_{2} \mathrm{O}\right):\end{array}$ & $\begin{array}{r}95 \\
87 \\
105\end{array}$ & $\begin{array}{l}4 \cdot 74 \\
6 \cdot 66 \\
7 \cdot 11\end{array}$ & $\begin{array}{r}94 \\
96 \\
108\end{array}$ & $\begin{array}{l}4.97 \\
6 \cdot 12 \\
6.93\end{array}$ & $\begin{array}{l}\text { ns } \\
\text { ns } \\
\text { ns }\end{array}$ \\
\hline $\begin{array}{l}\text { Before } \\
\text { After }\end{array}$ & $\begin{array}{l}3.4 \\
1.9\end{array}$ & $\begin{array}{l}0 \cdot 40 \\
0 \cdot 24\end{array}$ & $\begin{array}{l}2 \cdot 5 \\
1 \cdot 7\end{array}$ & $\begin{array}{l}0 \cdot 12 \\
0 \cdot 12\end{array}$ & $\begin{array}{c}\mathrm{P}<0.05 \\
\mathrm{~ns}\end{array}$ \\
\hline $\begin{array}{l}\text { Compliance } \\
\left.\text { (1./cmH } \mathrm{H}_{2} \mathrm{O}\right): \\
\text { Before } \\
\text { After }\end{array}$ & $\begin{array}{l}0 \cdot 34 \\
0 \cdot 44\end{array}$ & $\begin{array}{l}0.02 \\
0.04\end{array}$ & $\begin{array}{l}0 \cdot 27 \\
0 \cdot 32\end{array}$ & $\begin{array}{l}0.02 \\
0.05\end{array}$ & $\begin{array}{c}\text { ns } \\
P<0.05\end{array}$ \\
\hline $\begin{array}{l}\left.\text { PTLC ( } \mathrm{cmH}_{2} \mathrm{O}\right): \\
\text { Before } \\
\text { After } \\
\text { pH (units) } \\
\mathrm{PacO}_{2}(\mathrm{mmHg}) \\
\mathrm{PaO}_{2}(\mathrm{mmHg})\end{array}$ & $\begin{array}{l}14 \\
14 \\
7 \cdot 41 \\
34 \\
92\end{array}$ & $\begin{array}{l}1 \cdot 77 \\
1.40 \\
0 \cdot 005 \\
1 \cdot 14 \\
1 \cdot 50\end{array}$ & $\begin{array}{l}21 \\
21 \\
7 \cdot 40 \\
34 \\
94\end{array}$ & $\begin{array}{l}1 \cdot 70 \\
2 \cdot 10 \\
0 \cdot 002 \\
0 \cdot 72 \\
1 \cdot 82\end{array}$ & $\begin{array}{l}P<0.05 \\
P<0.05 \\
\text { ns } \\
\text { ns } \\
\text { ns }\end{array}$ \\
\hline
\end{tabular}

$\mathrm{TLC}=$ total lung capacity; $\mathrm{VC}=$ vital capacity; $\mathrm{FEV}_{1}=$ one-second fored expiratory volume; MVV=maximum voluntary ventilation; forced expiratory volume; $M V V=$ maximum voluntary ventilation
Pvisc $=$ mean pressure to overcome viscous resistance; PTLC $=$ trans$\mathrm{Pvisc}=$ mean pressure to overcome viscous resistance; $\mathrm{PTLC}=$ trans-
pulmonary pressure at full inspiration; $\mathrm{PaO}_{2}=$ arterial oxygen tension $\mathrm{PaCO}_{2}=$ arterial carbon dioxide tension; $\mathbf{B T P S}=$ body temperature and pressure saturated with water vapour; $\mathbf{S E M}=$ standard error of mean.

0.05). The abnormally low pressure after bronchodilatation occurred without increased total lung capacity. The mean values of arterial $\mathrm{pH}$, carbon dioxide tension, and oxygen tension were not significantly different in the two groups and were all within normal limits.

EXERCISE TESTS (Table III) There were no significant differences between the means of $\mathrm{FEV}_{1}$ before exercise, level of exercise work, and heart rate after six minutes' work, indicating that probably there was no difference in training in cycling or fitness between the groups. In fact the only significant difference in all the data shown in Table III were the $\mathrm{FEV}_{1}$ values after exercise. The probability of the differences being due to chance was less than 0.05 and 0.01 in the first and second minute after exercise. In seven patients the maximal decrease in $\mathrm{FEV}_{1}$ occurred between 1 and 3 minutes, in 10 patients it was between 10 and 14 minutes, and in only four between 28 and 30 minutes. The mean maximal decrease after exer-
T A B L E I I I

EFFECT OF EXERCISE ON FEV F $_{1}$ (I. BTPS) IN 42 PATIENTS WITH CHRONIC NONSPECIFIC LUNG DISEASE WITH (GROUP I) OR WITHOUT (GROUP II) EXERCISE-INDUCED AIRWAY OBSTRUCTION

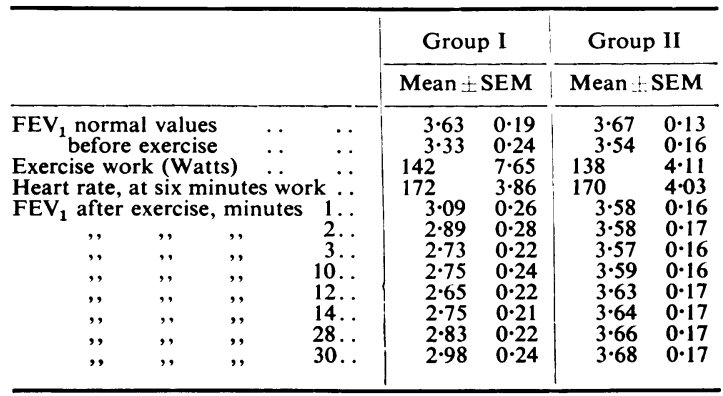

$\overline{\mathrm{SEM}}=$ standard error of mean.

cise was between 10 and 14 minutes and recovery began within the next 14 minutes. In the present study, 10 patients showed a maximal decrease of $\mathrm{FEV}_{1}$ of 10 to $20 \%$ of its pre-exercise value, in six patients it was 20 to $40 \%$, and in only four patients was it more than $40 \%$. Patients in group 2 showed no decrease in $\mathrm{FEV}_{1}$ after exercise. An increase of $\mathrm{FEV}_{1}$ occurred, although in the majority it was small. No correlation was noted between the decreased $\mathrm{FEV}_{1}$ and clinical features.

\section{DISCUSSION}

Investigations comparing two groups of patients suffering from chronic obstructive airway disease are difficult to standardize. We attempted to avoid the variability due to the disease by studying patients while they were in hospital and in a steady state of their disease. The data show that both groups of patients were relatively well, as can be seen from respiratory, blood, and exercise studies.

In this study, the subjects with exercise-induced airway obstruction did not differ from the control group in incidence or severity of respiratory symptoms and clinical findings. The present data show that both groups had similar pulmonary function and blood gases. The most significant differences were found in the elastic recoil estimated from the $\mathbf{P}_{\mathrm{TLC}}$ when compared with the group 2 values. In group 1 a decreased elastic recoil occurred with little expiratory airway obstruction at the time of the investigation. Penman, O'Neill, and Begley (1970) demonstrated that several patients with loss of lung recoil had no appreciable limitation of forced expiratory flow. Woolcock and Read (1968) suggested that long periods of marked hyperinflation with permanent stretching of the elastic 
elements of the lung tissue might have been responsible for the loss of elastic recoil. The investigations of Anderson, McEvoy, and Bianco (1972) have recently demonstrated that a marked hyperinflation occurs in patients with exerciseinduced airway obstruction after exercise, and that it seems to be spontaneously reversible. Thus, it is possible that the loss of elasticity in the patients of group 1 is secondary to repeated lung hyperinflation after exercise.

In the present investigation no connection could be demonstrated between post-exercise airway obstruction and an increase in airway responsiveness as detected by the histamine threshold. However, the coincidence of post-exercise airway obstruction and a concomitant increase in airway responsiveness to cold air, forced expirations or hyperventilation has recently been emphasized by Simonsson, Skoogh, and Ekström-Jodal (1972). Differences in technique and probably also in the patient's condition at the moment of investigation make it difficult to compare our results with those of Simonsson and co-workers. It is generally accepted that exercise-induced airway obstruction occurs after exercise in a large percentage of asthmatic patients, as defined by the Ciba Foundation Symposium (1959), and particularly in the younger age groups (Katz, 1970). In our experience, this phenomenon can also occur in older age groups and in patients belonging to the group of chronic obstructive lung diseases, as defined by Orie et al. (1961) and Fletcher (1961). The report of Simonsson and associates (1972) points in the same direction.

In our experience, the clinical condition of the patient influences the presence of post-exercise airway obstruction: when investigated during absence of complaints, it is often not possible to reproduce the phenomenon. In one patient we were able to demonstrate the obstruction after exercise only when he had a bacterial bronchitis. A second patient only showed exercise-induced airway obstruction 24 hours after a positive reaction to the inhalation of house dust. Thus, it is possible that the inconsistency of the reports in the literature may be due at least partly to these concomitant factors.

\section{CONCLUSION}

After exercise a certain number of patients with chronic obstructive lung disease increase their airway resistance to a greater extent than do healthy individuals. The same can be said about the bronchial obstructing activity (de Vries et al.,
1964) of various physical and chemical stimuli. It is consistent with reports from the literature that the increased 'responsiveness' of the airways to exercise in this group of patients may be considered a manifestation of the obstructive lung disease and that exercise may act as a triggering mechanism.

The authors are indebted to Professor Dr. N. G. M. Orie for reviewing this manuscript, and to Miss $R$. Venema for technical assistance.

\section{REFERENCES}

Anderson, S. D., McEvoy, J. D. S., and Bianco, S. (1972). Changes in lung volumes and airway resistance after exercise in asthmatic subjects. American Review of Respiratory Diseases, 106, 30.

Åstrand, P. O., and Rodahl, K. (1970). Textbook of Work Physiology, p. 281. McGraw-Hill, New York.

Booy-Noord, H., Orie, N. G. M., ten Cate, H. J., Sloots, S., and Bolt, D. (1957). The influence of various drugs on the vital capacity of asthmatics. International Archives of Allergy, 10, 321.

Crompton, G. K. (1968). An unusual example of exerciseinduced asthma. Thorax, 23, 165.

Fisher, H. K., Holton, P., Buxton, R. St. J., and Nadel, J. A. (1970). Resistance to breathing during exerciseinduced asthma attacks. American Review of Respiratory Diseases, 101, 885.

Fletcher, C. M. (1961). Definition and classification of bronchitis, asthma and emphysema. In: Bronchitis: an International Symposium, 1960, edited by N. G. M. Orie and H. J. Sluiter, p. 273. Royal van Gorcum, Assen, the Netherlands.

Hilvering, Chr. (1963). Longmechanische onderzoekingen bij patienten met long-tuberculose. Thesis, Groningen.

Jones, R. S., Wharton, M. J., and Buston, M. H. (1963). The place of physical exercise and bronchodilator drugs in the assessment of the asthmatic child. Archives of Diseases in Childhood, 38, 539.

Katz, R. M. (1970). Exercise induced bronchospasm in childhood. Annals of Allergy, 28, 361 .

Orie, N. G. M., Sluiter, H. J., de Vries, K., and Tammeling, G. J. (1961). Chronische aspecifieke respiratoire aandoeningen. Nederlands Tijdschrift voor Geneeskunde, $105,2136$.

Penman, R. W. B., O'Neill, R. P., and Begley, L. (1970). Lung elastic recoil and airway resistance as factors limiting forced expiratory flow. American Review of Respiratory Diseases, 101, 528.

Simonsson, B. G., Skoogh, B. E., and Ekström-Jodal, B. (1972). Exercise-induced airway constriction. Thorax, $27,169$.

Stanescu, D. C., and Teculescu, D. B. (1970). Exercise- and cough-induced asthma. Respiration, $27,377$. 
Tammeling, G. J., Sluiter, H. J., Hilvering, Chr., and Berg, W. Chr. (1971). Transpulmonary pressure at full inspiration and dynamics of the airways in patients with obstructive lung disease. American Review of Respiratory Diseases, 103, 38.

Vasallo, C. L., Gee, J. B. L., and Domm, B. M. (1972). Exercise-induced asthma. Observations regarding hypocapnia and acidosis. American Review of Respiratory Diseases, 105, 42.
Vries, K. de, Booy-Noord, H., Goei, J. T., Grobler, N. J., Sluiter, H. J., Tammeling, G. J., and Orie, N. G. M. (1964). Hyperreactivity of the bronchial tree to drugs, chemical and physical agents. In: Bronchitis: Second International Symposium, 1964, edited by N. G. M. Orie and H. J. Sluiter, p. 167. Royal van Gorcum, Assen, the Netherlands.

Woolcock, A. J., and Read, J. (1968). The static elastic properties of the lungs in asthma. American Review of Respiratory Diseases, 98, 788. 